\title{
Rancang Bangun Robot Berbasis PDA
}

\author{
Sritrusta Sukaridhoto, Titon Dutono, Nonot Harsono, Amang Sudarsono, Akuwan Saleh, Arief Furqon, Endro Subko, \\ Firman Yuriansyah, Irfan Syafur Bachtiar \\ Electrical Engineering Polytechnic Institute of Surabaya (EEPIS), \\ Institut Teknologi Sepuluh Nopember (ITS), Surabaya, Indonesia \\ E-mail : dhoto@eepis-its.edu
}

\begin{abstract}
ABSTRAK
Dunia robotika saat ini berkembang sangat pesat , ada robot yang bergerak sendiri ( otomatis) dan ada robot yang digerakkan secara jarak jauh (remote). Untuk menggerakkan robot secara jarak jauh dengan nirkabel dibutuhkan suatu interface antara pengontrol nya dan robot itu sendiri, dan interfacing yang digunakan pun bermacam-macam. Pada paper ini digunakan Personal Digital Assistant (PDA) atau biasa disebut Pocket PC sebagai pusat interfacing pengontrol robot. Dengan memanfaatkan komunikasi wireless yang sudah terintegrasi robot tersebut dapat dikendalikan dengan perangkat nirkabel lainnya seperti PDA, mobile phone, dan PC yang dilengkapi dengan wireless card.

Pada proyek ini telah berhasil dibangun sebuah robot berbasis PDA yang dapat dikendalikan secara jarak jauh dengan komunikasi nirkabel.
\end{abstract}

Kata kunci: Robotika, PDA, Komunikasi nirkabel.

\section{PENDAHULUAN}

Pada teknologi robot saat ini, permasalahan interfacing untuk mengontrol robot dapat menjadi suatu persoalan tersendiri. Sedangkan penggunaan media kabel untuk mengontrol robot dirasakan kurang efektif, dengan keterbatasan dari panjang kabel itu sendiri.Sehingga media wireless dapat menjadi pilihan yang lebih efektif. Untuk mengontrol robot secara jarak jauh dengan media wireless kita harus menambahkan suatu modul interface seperti wireless card, bluetooth, atau infrared. Dalam hal tertentu menambahkan suatu modul tersebut untuk digabungkan mempunyai kerumitan tersendiri. Untuk mengendalikan sebuah robot ditanamkan sebuah microcontroller atau mikroprosessor sebagai otak dari robot tersebut, dan modul interfacenya pun juga harus kita hubungkan Seiring tugas dan fungsi robot tersebut, fungsi dari mikrokontroller pun akan semakin rumit. Dan untuk itu diperlukan sebuah mikrokontroller yang handal

Pada penelitian ini digunakan sebuah PDA ( Personal Digital Assistant) yang sudah terintegrasi dengan wifi, bluetooth, sebagai solusi permasalahan komunikasi sehingga robot tersebut mempunyai beberapa cara koneksi atau disebut multi koneksi. Untuk pengendali dari robot itu sendiri juga digunakan beberapa cara yaitu mengendalikan dengan menggunakan PDA, mobile phone atau hand phone, dan voice command yang diproses pada PC dengan wireless card . Setiap pengendali tersebut mengirimkan data ke PDA lalu akan dikirim kembali ke mikrokontroller pada robot untuk mendriver motor. Sehingga penelitian ini menghasilkan sebuah non autonomous robot yang multi koneksi dan multi kontroller berbasis pada PDA.

\section{ROBOT PDA}

Robot PDA adalah aplikasi yang dibuat dari PDA. Dimana aplikasi ini memanfaatkan konektifitas yang terdapat dalam PDA seperti Wi-Fi, Bluetooth sebagai media pengendali wireless-nya. Selain itu digunakan juga sebagai "otak" pengganti komputer yang dapat menterjemahkan perintah yang di terima dari berbagai aplikasi pengontrolan dan koneksi. Dalam proyek ini disamakan untuk data yang diterima dari setiap kontrol adalah berupa karakter ASCII 2 untuk maju, 8 untuk mundur, 4 untuk kiri, 6 untuk kanan dan 5 untuk berhenti.

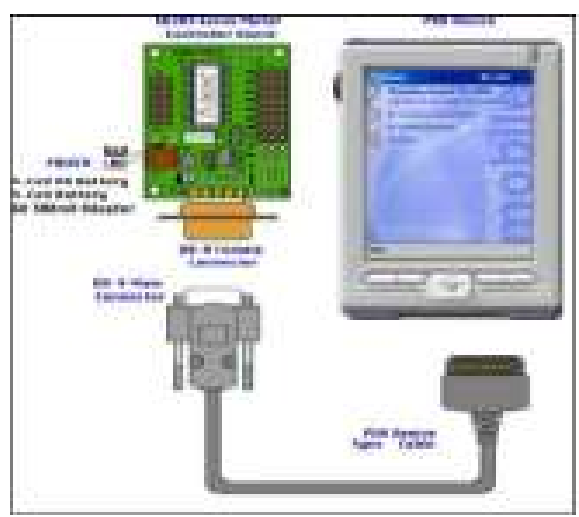

Gambar 1. Koneksi PDA dengan Mikrokontroller

\subsection{Koneksi}

2.1.1 Wi-Fi

Wi-Fi (atau wifi) merupakan kependekan dari Wireless Fidelity, memiliki pengertian yaitu sekumpulan standar yang digunakan untuk Jaringan Lokal Nirkabel (Wireless Local Area Networks WLAN) yang didasari pada spesifikasi IEEE 802.11. Standar terbaru dari spesifikasi 802.11a atau b, seperti $802.16 \mathrm{~g}$, saat ini sedang dalam penyusunan, spesifikasi terbaru tersebut menawarkan banyak 
peningkatan mulai dari luas cakupan yang lebih jauh hingga kecepatan transfernya.

Wi-Fi dirancang berdasarkan spesifikasi IEEE 802.11. Sekarang ini ada empat variasi dari 802.11, yaitu: 802.11a, 802.11b, 802. 11g, and $802.11 \mathrm{n}$. Spesifikasi b merupakan produk pertama Wi-Fi. Dan pada proyek ini menggunakan standart IEEE 802.1 1b

Tabel 1. Spesifikasi IEEE 802.11

\begin{tabular}{|lllll|}
\hline Protocol & $\begin{array}{l}\text { Frekuenc } \\
\text { y (GHz) }\end{array}$ & $\begin{array}{l}\text { Data } \\
\text { Rate }\end{array}$ & $\begin{array}{l}\text { Range } \\
\text { (indoor) }\end{array}$ & $\begin{array}{l}\text { Range } \\
\text { (outdoor }\end{array}$ \\
\hline Legacy & $\mathbf{2 . 4}-\mathbf{2 . 5}$ & $\mathbf{2 ~ M B}$ & $\mathbf{7}$ & $\mathbf{7}$ \\
\hline 802.11a & $\mathbf{5}$ & $\mathbf{5 4} \mathbf{M B}$ & $\begin{array}{l}\sim 30 \\
\text { meter }\end{array}$ & $\mathbf{7}$ \\
\hline 802.11b & $\mathbf{2 . 4 - 2 . 5}$ & $\mathbf{1 1} \mathbf{M B}$ & $\begin{array}{l}\sim 30 \\
\text { meter }\end{array}$ & $\mathbf{7}$ \\
\hline 802.11g & $\mathbf{2 . 4 - 2 . 5}$ & $\mathbf{5 4} \mathbf{M B}$ & $\begin{array}{l}\sim 30 \\
\text { meter }\end{array}$ & $\mathbf{7}$ \\
\hline 802.11n & $\mathbf{2 . 4 / 5}$ & $\mathbf{5 4 0}$ & $\begin{array}{l}\sim 50 \\
\text { meter }\end{array}$ & $\begin{array}{l}\sim 125 \\
\text { meter }\end{array}$ \\
\hline
\end{tabular}

\subsubsection{Bluetooth}

Bluetooth adalah sebuah teknologi komunikasi wireless (tanpa kabel) yang beroperasi dalam pita frekuensi 2,4 GHz unlicensed ISM (Industrial, Scientific and Medical) dengan menggunakan sebuah frequency hopping tranceiver yang mampu menyediakan layanan komunikasi data dan suara secara real-time antara host-host bluetooth dengan jarak jangkauan layanan yang terbatas (sekitar 10 meter). Bluetooth sendiri dapat berupa card yang bentuk dan fungsinya hampir sama dengan card yang digunakan untuk wireless local area network (WLAN) dimana menggunakan frekuensi radio standar IEEE 802.11, hanya saja pada bluetooth mempunyai jangkauan jarak layanan yang lebih pendek dan kemampuan transfer data yang lebih rendah.

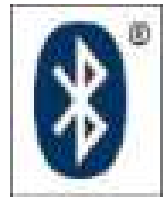

Gambar 2. Lambang Bluetooth

\subsection{Perangkat Keras}

\subsubsection{Minimum si stem robot}

\subsubsection{Mikrokontroller}

Mikrokontroler merupakan suatu komponen elektronika yang didalamnya terdapat rangkaian mikroprosesor, memori (RAM/ROM) dan I/O, rangkaian tersebut terdapat dalam level chip atau biasa disebut single chip microcomputer. Jenis Mikrokontroller yang digunakan adalah AT89S51

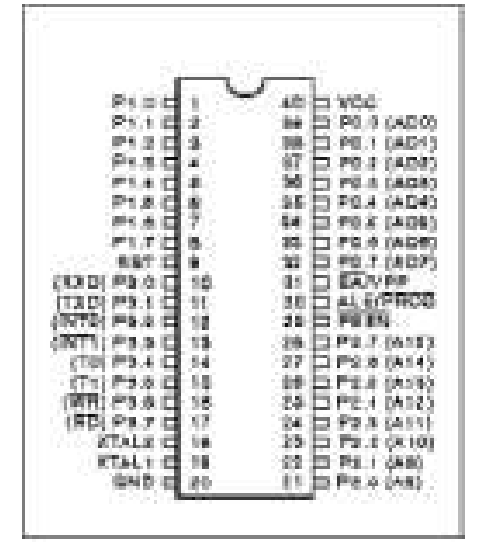

Gambar 3. Mikrokontroller AT89S51

\subsubsection{Rangkaian minimum si stem}

Sistem ini merupakan pusat pemrosesan dari beberapa sistem pendukung yang lainnya, dimana system rangkaian ini mengendalikan perangkat input dan output dan juga sebagai pusat expander dari beberapa alat yang akan digunakan pada saat digunakan kelak.

Rangkaian minimum system mikrokontroler ini terdiri dari rangkaian clok yang berupa kristal 11.0592 MHZ dan rangkaian reset

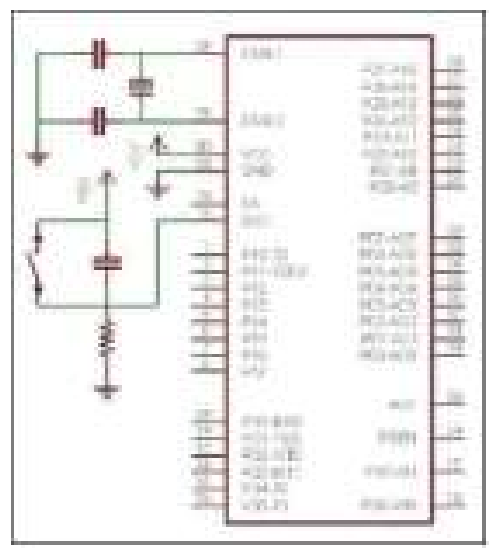

\subsubsection{PDA}

Aplikasi diinstall pada PDA tipe Ipaq RX 3175 dengan spesifikasi pada Tabel 2.

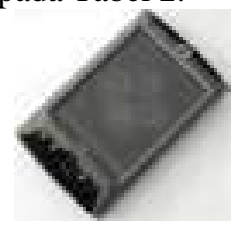

Gambar 5. PDA tipe IPAQ Rx 3175 yang digunakan 
Tabel 2. Spesifikasi PDA

\begin{tabular}{|l|l|}
\hline Operating System & $\begin{array}{l}\text { Windows Mobile 2003 Second } \\
\text { Edition }\end{array}$ \\
\hline Storage Space & 128MB ROM dan 64MB RAM \\
\hline $\begin{array}{l}\text { Screen Size and } \\
\text { Type }\end{array}$ & $\begin{array}{l}\text { 240x320 pixel QVGA 3.5" TFT } \\
\text { active-matrix display, with } \\
\text { Portrait and Landscape display }\end{array}$ \\
\hline $\begin{array}{l}\text { Processor Speed } \\
\text { and Type }\end{array}$ & $\begin{array}{l}\text { Samsung S3C 2440 processor @ } \\
\text { 400MHz }\end{array}$ \\
\hline Wireless & $\begin{array}{l}\text { Bluetooth (Class II device; up } \\
\text { to 4 dBm transmit, typical 10 } \\
\text { meter range) } \\
\text { Wi-Fi 802.11b } \\
\text { Consuer IR }\end{array}$ \\
\hline
\end{tabular}

\subsubsection{Mobile Phone}

Mobile Phone yang di gunakan adalah Nokia dengan tipe E70.

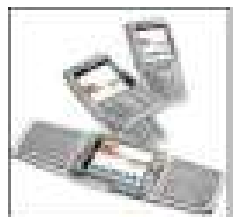

Gambar 6. Nokia E70

Tabel 3. Spesifikasi Mobile Phone

\begin{tabular}{|l|}
\hline \multicolumn{1}{|c|}{ Sistem Operasi: } \\
\hline \multicolumn{1}{|c|}{ Developer Platform: } \\
\hline \multicolumn{1}{|c|}{ Teknologi JAVA: } \\
\hline S60 3rd Edition \\
\hline MIDP 2.0 Memory \\
\hline CLDC 1.1 \\
\hline JSR 135 Mobile Media API \\
\hline JSR 205 Wireless Messaging API \\
\hline JSR 82 Bluetooth API \\
\hline \multicolumn{1}{|c|}{ Meran 9.1} \\
\hline NAND Memory: 128 MB \\
\hline SDRAM Memory: 64 MB \\
\hline Memory Card: Mini SD \\
\hline Max Memory Card Size: 2 GB \\
\hline \multicolumn{1}{c|}{ Konektivitas: } \\
\hline Bluetooth, Infrared, WLAN \\
\hline $\begin{array}{l}\text { USB, USB 2.0, USB Cable Nokia CA-53, } \\
\text { USB Cable Nokia DKU-2, USB Mass } \\
\text { Storage }\end{array}$ \\
\hline
\end{tabular}

2.2.4 Komputer

Digunakan untuk aplikasi pengenalan wicara, dengan spesifikasi seperti Tabel 4 .
Tabel 4. Spesifikasi Komputer

\begin{tabular}{|c|l|l|}
\hline NO & DESKRIPSI & \multicolumn{1}{c|}{ SPESIFIKASI } \\
\hline 1 & $\begin{array}{l}\text { Processor } \\
\text { model }\end{array}$ & $\begin{array}{l}\text { Intel(R) Pentium(R) 4 CPU } \\
3.00 \mathrm{GHz}\end{array}$ \\
\hline 2 & Memory & $512 \mathrm{MB}$ DDRAM \\
\hline 3 & HDD & $40 \mathrm{~GB}, 7200 \mathrm{rpm}$ \\
\hline 4 & Sound Card & $\begin{array}{l}\text { Creative Sound Blaster } \\
\text { Live 5.1 }\end{array}$ \\
\hline 5 & Microphone & Sony F-V620 \\
\hline 6 & Power & $400 \mathrm{~W}$ \\
\hline 7 & $\begin{array}{l}\text { Operating } \\
\text { System }\end{array}$ & Linux/GNU Debian \\
\hline 8 & Kernel & $2.6 .18-2-686$ \\
\hline
\end{tabular}

\subsection{Perangkat Lunak}

Perangkat lunak yang digunakan untuk membuat aplikasi di PDA adalah Microsoft Embedded Visual Basic 3.0 yang merupakan bagian dari Microsoft Embedded Visual Tools. Pada Windows Mobile Edition PDA digunakan pemrograman socket winsock ( windows socket ) untuk melakukan komunikasi jaringan baik secara nirkabel maupun

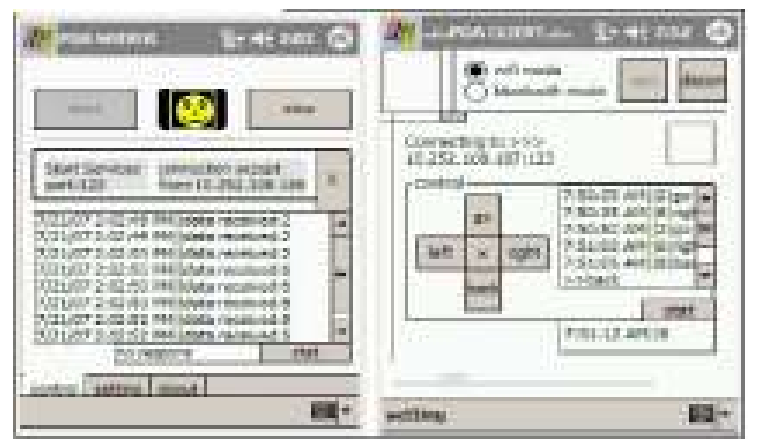

Gambar 7. Tampilan aplikasi pada PDA

Pada pemrograman aplikasi mobile phone digunakan Java2 Micro Edition atau yang biasa disebut J2ME, yaitu lingkungan pengembangan yang didesain untuk meletakkan perangkat lunak Java pada barang elektronik beserta perangkat pendukungnya. Untuk pemrograman socket digunakan socket berbasis Java Socket.

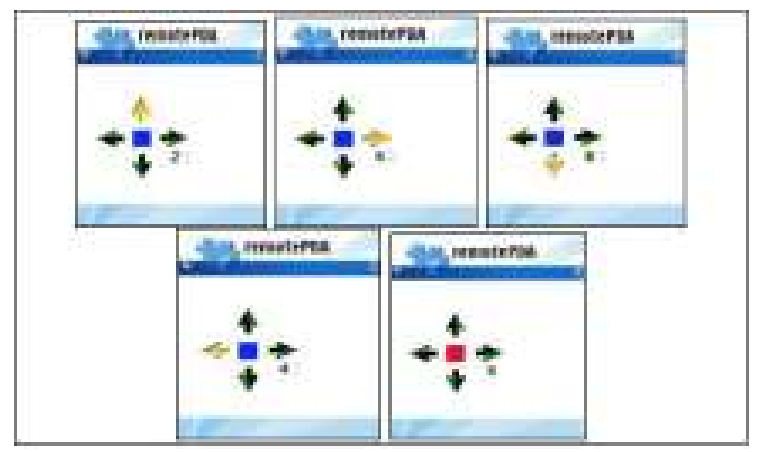

Gambar 8. Tampilan aplikasi pada mobile phone

Untuk pengenalan wicaranya menggunakan software Hidden Markov Model Toolkit (HTK), 
adalah tool atau perangkat lunak yang mudah digunakan untuk membangun dan memanipulasi Hidden Markov Model. HTK pada dasarnya digunakan untuk penelitian mengenai pengenalan suara meskipun juga digunakan untuk sejumlah aplikasi yang lain termasuk penelitian dalam suara sintetis, pengenalan karakter, dan pengurutan DNA. HTK terdiri dari kumpulan beberapa modul librabry dan tool dalam bahasa C. Perangkat-perangkat tersebut memberikan fasilitas yang handal untuk speech analysis, HMM training, testing dan results analysis. Perangkat lunak ini mendukung HMM baik yang menggunakan continuous density mixture Gaussians atau discrete distributions dan juga bisa digunakan untuk membangun sistem HMM yang komplek.

Kemudian untuk pemrograman socket digunakan tipe UNIX socket yang dibuat dengan bahasa $\mathrm{C}$. Untuk compiler C di Linux digunakan GCC (GNU C Compiler). Setelah pengenalan suara dan pemrograman socketnya selesai, keduanya digabungkan pada satu program shell supaya langsung bisa berjalan otomatis. Shell programming merupakan kumpulan perintah dasar dalam sistem operasi keluarga unix. Dengan shell programming kita dapat memanipulasi data dari suatu program

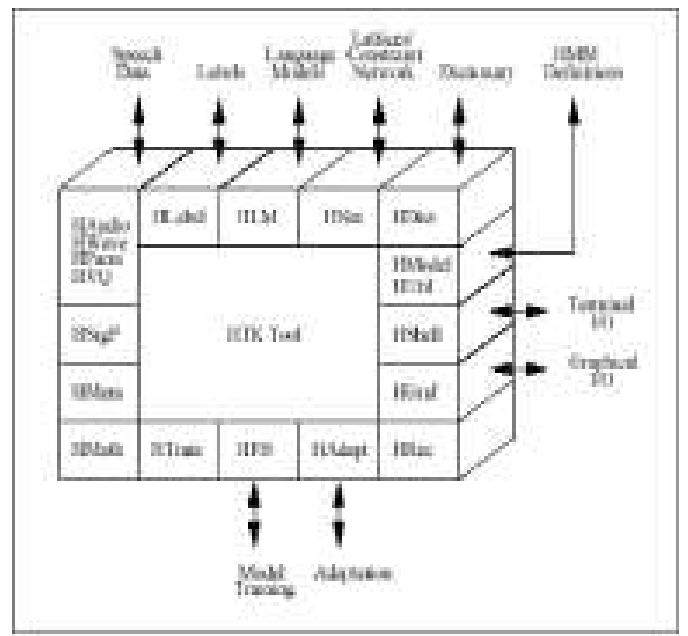

Gambar 9. Arsitektur HTK

\section{Pengujian Sistem}

Pengujian ini dilakukan untuk melihat hasil dari sistem yang telah dibuat dengan melihat setiap respon yang dilakukan oleh robot terhadap semua kontrol yang ada seperti di tunjukkan Gambar 11 :

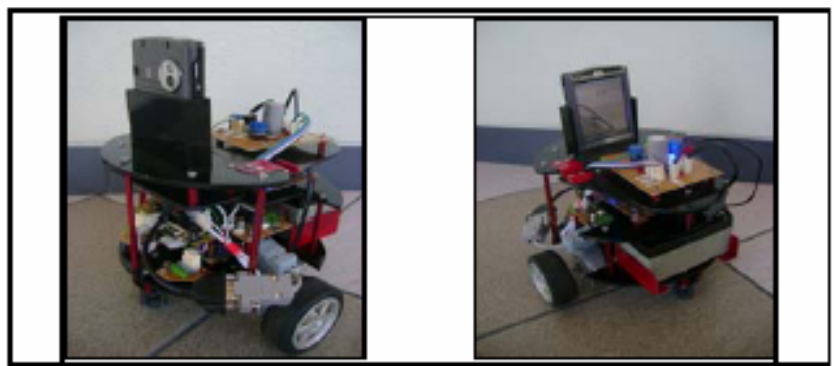

Gambar 10. Tampilan Robot yang sudah terintegrasi dari 2 posisi

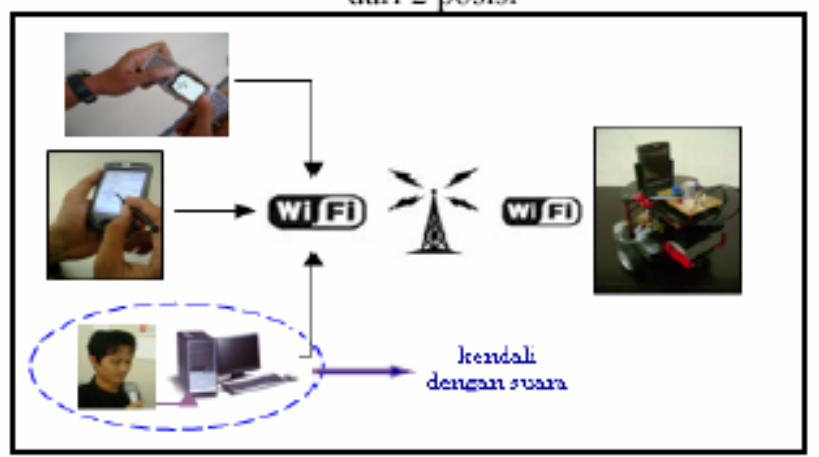

Gambar 11. Skema Kontrol Robot PDA

\subsection{Koneksi}

\subsubsection{Wi-fi}

Kondisi sinyal wifi mempengaruhi konektifitas dan kecepatan data yang dapat dikirim. Pada pengujian dengan kondisi siyal low, medium , dan excellent data dapat terkirim dengan cepat dan lancar. Hal itu dikarenakan data yang dikirim tidak besar hanya 1 byte sehingga biarpun pada kondisi kecepatan minimum ( sinyal low) data masih dapat dikirim dengan baik selama masih terjadi koneksi antara Client dan Server.

Pada pengujian komunikasi dengan perangkat PDA dan Handphone pengujian waktu transfer dapat dilihat sampai dengan satuan milisecond (ms) .Tetapi antara aplikasi pada PDA dan HP menggunakan cara yang berbeda dalam pemrogramannya untuk mendapatkan respon dalam satuan ms , sehingga data yang didapat menunjukan perbedaan yang jauh antara respon PDA dan HP dimana respon PDA jauh lebih cepat dibandingkan dengan handphone.

Untuk pengujian koneksi wifi dengan kendali suara yang diproses pada PC dengan wireless card diambil waktu transfer dengan satuan detik karena untuk analisa pada mode koneksi ini lebih dikhusukan pada pengenalan suaranya bukan pada waktu transfer data. 


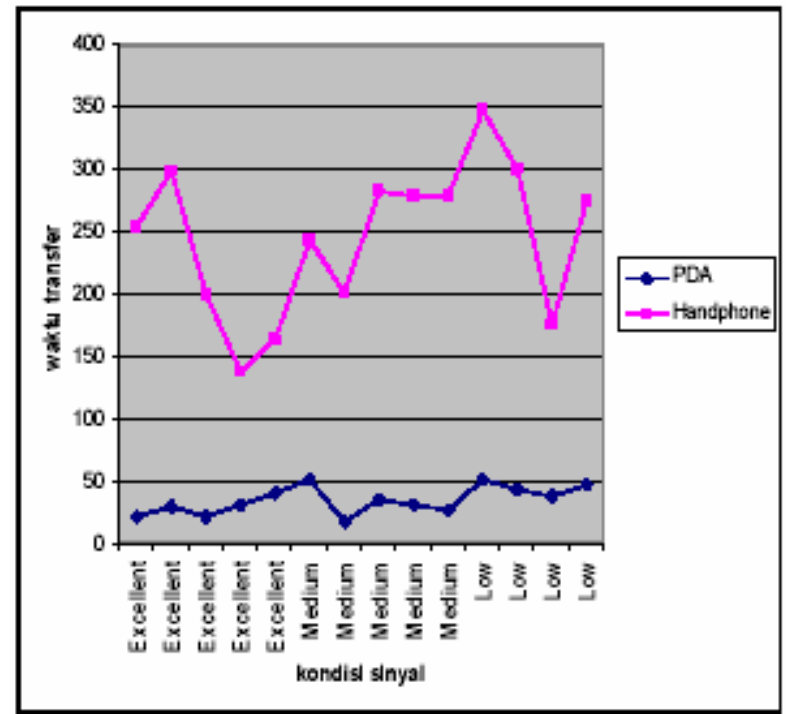

Gambar 12. Grafik perbandingan waktu transfer antara PDA dan mobile phone

\subsubsection{Bluetooth}

Untuk mode koneksi bluetooth digunakan jika tidak terdapat koneksi wifi didaerah tersebut, tetapi dengan syarat antara PDA Client dan PDA Server masih di dalam jarak jangkau sehingga perlu dilakukan pengujian terhadap jarak jangkau maksimum dari bluetooth yang digunakan. Kemudian hasil pengujian dibandingkan dengan model koneksi wifi , dimana jarak yang ditempuh untuk koneksi wifi dapat lebih jauh dengan pengiriman data yang sama. Sedangkan untuk waktu trasnfer nya hampir sama yaitu dibawah satu detik.

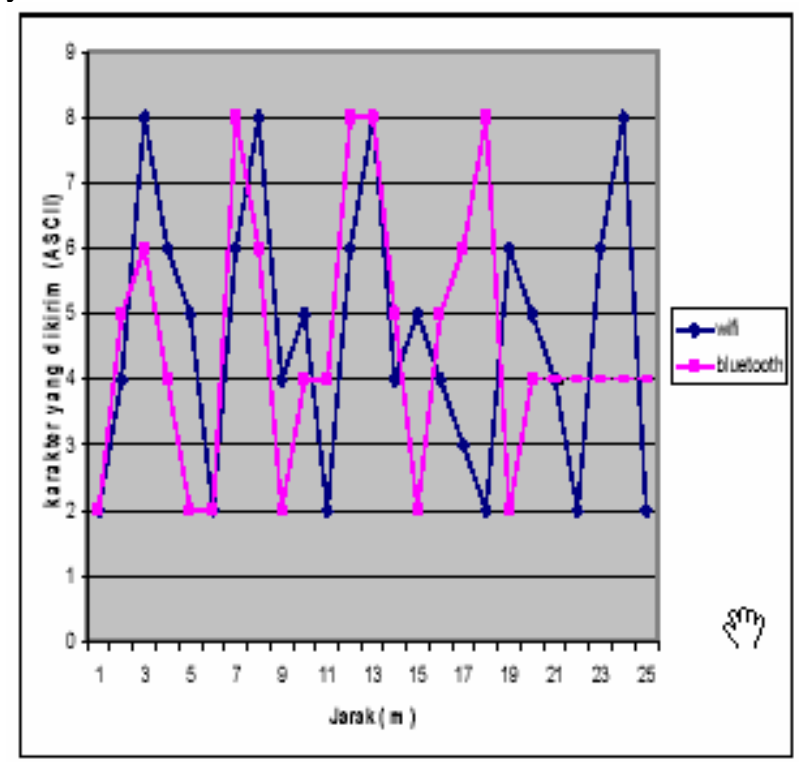

Gambar 13. Perbandingan jarak jangkau antara koneksi bluetooth dan wifi.

\subsubsection{Suara}

Pengujian ini dilakukan dengan memberikan perintah terhadap robot sebanyak 20 kali secara acak untuk kelima perintah yang telah di tentukan dengan metode independent speaker :
Tabel 5. Pengujian metode Independent speaker dengan robot PDA

\begin{tabular}{|l|l|l|l|}
\hline No & Perintah & Gerak Robot & Waktu (s) \\
\hline 1 & Kanan & Stop & $\mathbf{7}$ \\
\hline 2 & Maju & Maju & $\mathbf{4}$ \\
\hline $\mathbf{J}$ & Kiri & Kiri & $\mathbf{5}$ \\
\hline 4 & Mundur & Mundur & $\mathbf{5}$ \\
\hline 5 & Kanan & Stop & $\mathbf{8}$ \\
\hline 6 & Kiri & Stop & $\mathbf{6}$ \\
\hline 7 & Mundur & Mundur & $\mathbf{5}$ \\
\hline 8 & Maju & Maju & $\mathbf{5}$ \\
\hline 9 & Stop & Stop & $\mathbf{4}$ \\
\hline 10 & Maju & Maju & $\mathbf{4}$ \\
\hline 11 & Kiri & Kiri & $\mathbf{5}$ \\
\hline 12 & Mundur & Mundur & $\mathbf{4}$ \\
\hline 13 & Stop & Stop & $\mathbf{5}$ \\
\hline 14 & Mundur & Mundur & $\mathbf{4}$ \\
\hline 15 & Kanan & Stop & $\mathbf{7}$ \\
\hline 16 & Maju & Maju & $\mathbf{4}$ \\
\hline 17 & Kiri & Kiri & $\mathbf{5}$ \\
\hline 18 & Mundur & Stop & $\mathbf{8}$ \\
\hline 19 & Maju & Maju & $\mathbf{5}$ \\
\hline 20 & Stop & Stop & $\mathbf{5}$ \\
\hline
\end{tabular}

\subsection{Respon Robot}

Beban yang ditanggung oleh robot adalah sebagai berikut:

Tabel 6. Beban Robot PDA

\begin{tabular}{|l|l|l|}
\hline \multicolumn{1}{|c|}{ Nama beban } & Jumlah & \multicolumn{1}{c|}{ Berat } \\
\hline Pda ipaq rx 3000 & $\mathbf{1}$ & 165 gr \\
\hline Batrey 12V DC, 1.2 A & $\mathbf{1}$ & 400 gr \\
\hline Minimum system & $\mathbf{1}$ & $\mathbf{1 0}$ gr \\
\hline Driver motor DC & $\mathbf{2}$ & $\mathbf{1 0}$ gr \\
\hline Motor dc 12 V & $\mathbf{2}$ & 200 gr \\
\hline Rangkaian dan baut & - & $\mathbf{1 0}$ gr \\
\hline Berat Total Beban & & 795 gr \\
\hline
\end{tabular}

Tabel 7. Kecepatan Putaran Motor Statis

\begin{tabular}{|l|l|l|l|}
\hline \multirow{2}{*}{ Karakter } & \multirow{2}{*}{ Gerakan } & \multicolumn{2}{|c|}{ Kecepatan (rpm) } \\
\cline { 3 - 4 } & & kanan & kiri \\
\hline 2 & Maju & 277 & 262 \\
\hline 8 & Mundur & 270 & 255 \\
\hline 4 & Belok kanan & 000 & 261 \\
\hline 6 & Belok kiri & 278 & 000 \\
\hline 5 & Diam & 00.00 & 00.00 \\
\hline
\end{tabular}

Tabel 8. Kecepatan Motor Berbeban

\begin{tabular}{|l|l|l|l|}
\hline Karakter & \multirow{2}{*}{ Gerakan } & \multicolumn{2}{|c|}{ Kecepatan (rpm) } \\
\cline { 3 - 4 } & & kanan & kiri \\
\hline 2 & Maju & 250 & 235 \\
\hline 8 & Mundur & 266 & 230 \\
\hline 4 & Belok kanan & 000 & 230 \\
\hline 6 & Belok kiri & 278 & 000 \\
\hline 5 & Diam & 000 & 000 \\
\hline
\end{tabular}


Pengujian ini dilakukan dengan menghitung waktu respon robot dengan kontrol yang diberikan. Dimana robot dalam keadaan bebas tidak menyentuh lantai

Tabel 9. Pengujian Reaksi Statis

\begin{tabular}{|c|l|l|}
\hline No & \multicolumn{1}{|c|}{ Reaksi Robot } & Waktu (s) \\
\hline 1 & Maju & 2.0 \\
\hline 2 & Mundur & 2.0 \\
\hline 3 & Belok Kanan & 2.7 \\
\hline 4 & Belok Kiri & 2.8 \\
\hline 5 & Berhenti & 3.0 \\
\hline
\end{tabular}

Pengujian ini dilakukan dengan cara menjalankan motor di lantai dan dihitung respon waktu yang dibutuhkan robot terhadap kontrol.

Tabel 10. Pengujian Reaksi Dinamis

\begin{tabular}{|c|l|l|}
\hline No & \multicolumn{1}{|c|}{ Reaksi Robot } & Waktu (s) \\
\hline 1 & Maju & $\mathbf{2 . 5}$ \\
\hline 2 & Mundur & $\mathbf{2 . 4}$ \\
\hline 3 & Belok Kanan & $\mathbf{3 . 0}$ \\
\hline 4 & Belok Kiri & $\mathbf{3 . 1}$ \\
\hline 5 & Berhenti & $\mathbf{3 . 0}$ \\
\hline
\end{tabular}

\section{KESIMPULAN}

1. Pada project ini robot sudah dapat di dikendalikan secara realtime pada perangkat PDA dan mobile phone, sedangkan untuk kendali suara masih terdapat delay dari pengenalan suara itu sendiri.

2. Pada sistem ini data dapat terkirim dengan baik pada berbagai kondisi sinyal, baik pada kondisi terbaik ataupun lemah. Data yang dikirim berupa karakter ASCII sebesar 1 Byte.

3. Penggunaaan device dan tipe socket yang berbeda (windows socket, java socket, unix socket) tidak mempengaruhi pengiriman data selama komunikasi data menggunakan satu protokol yang sama.

4. Model koneksi bluetooth mempunyai jarak jangkau yang terbatas tergantung dari spesifikasi bluetooth yang digunakan. Jarak yang melebihi batas menyebabkan data tidak dapat terkirim.

\section{DAFTAR PUSTAKA}

[1] Williams H.Douglas, PDA Robotics, McGrawHill, 2003.

[2] Microsoft Corporation, Cambridge University Engineering Department, HTK Book (2001-2005). htkbook.pdf

[3] Nicolas Moreau, "Htk-basic-tutorial.pdf", Microsoft Corporation, Cambridge University Engineering Department, 2002

[4] Jim Geier, Wireless Networks First - Step, Cisco Press, 2005

[5] Brian Hall, "Beej's Guide to Network Programming Using Internet Sockets", 1995-2001

[6] Feri Djuandi, Pemrograman pada PocketPC, ElexMedia Komputindo, Jakarta, 2004.

[7] Paulus Andi Nalwan, Panduan Praktis Teknik Antar Muka dan Pemrograman Mikrokontroller AT89S51,2003

[8] Topley, Kim, " J2ME in Nutshell", 2002

[9] Wells, Martin, "J2ME Game Programming", 2004

[10] Knudsen, Jonathan, " Wireless Java Developing with J2ME, Second Edition".

[11] Riggs,Roger. Taivalsaari, Antero, team. "Programming Wireless Devices with the JavaTM 2 Platform, Micro Edition, Second Edition", 2003

[12] Endro Subko, Sritrusta Sukaridhoto, Akuwan Saleh, "Rancang Bangun Robot PDA Berbasis Embedded System Menggunakan Pocket PC", Tugas Akhir EEPIS-ITS, 2007

[13] Arief Furqon, Sritrusta Sukaridhoto, Nonot Harsono, "Software Aplikasi Pengontrol Gerakan Robot PDA Berbasis Wireless LAN pada Pocket PC", Tugas Akhir EEPIS-ITS, 2007

[14] Firman Yuriansyah, Sritrusta Sukaridhoto, Amang Surdarsono, "Aplikasi Kontrol Gerakan Robot PDA Berbasis Client - Server pada Mobile Phone", Tugas Akhir EEPIS-ITS, 2007

[15] Irfan Syafur Bachtiar, Sritrusta Sukaridhoto, Titon Dutono, "Aplikasi Pengenalan Wicara HMM untuk Kendali Robot PDA", Tugas Akhir EEPIS-ITS, 2007. 